\title{
We're All In This Together: Identifying Meaningful Outcomes for K-6 Students of Teacher Candidates
}

\author{
Mary Fisher and Anne Ociepka \\ School of Education
}

\begin{abstract}
Connecting K-6 student outcomes with teacher preparation programs remains a critical need for the field (Bondy, 2004, Cochran-Smith, 2006). Even while we have begun to sort through and document outcomes for teacher interns relative to national standards, the task of connecting performance to K-6 student outcomes has been little documented. This interview study identified what mentor teachers associated with one urban teacher preparation program believed are positive student and associated mentor outcomes that result from student teacher participation in their elementary classrooms. This interview study consisted of an emergent analysis of individual interviews with sixteen student teacher mentors using an interview guide with a set of six questions. Data from a teacher candidate focus group which addressed a subset of these questions served to triangulate this analysis. Findings are shared in light of implications for teacher educators and their use by teacher education programs for in-depth follow-up studies. This local study, while unique to our own institution, relied on the use of a promising practice that is, including the voice of mentor teachers - and its findings broadened the participant stakeholder base beyond the usual limited representation of university teacher educators and university researchers only.
\end{abstract}

